\title{
MAKNA SIMBOLIK RITUAL RATIB BERJALAN PADA TRADISI TOLAK BALA: STUDI DESA SUNGAI KURUK III KECAMATAN SERUWAY KABUPATEN ACEH TAMIANG
}

\author{
Awaluddin Arifin ${ }^{1}$, Subhani ${ }^{1}$, Rabiah ${ }^{1}$ \\ 1 Program Studi Ilmu Komunikasi, Fakultas Ilmu Sosial dan Ilmu Politik, \\ Universitas Malikussaleh
}

Korespondesi: awaludin.arifin@unimal.ac.id

\begin{abstract}
This research is entitled about the Symbolic Meaning of Ritual Ratib Walking in the Tolak Bala Tradition (Study of Sungai Kuruk III Village, Seruway District, Aceh Tamiang Regency). This research focuses on the process of implementing the walking ratib ritual and the symbolic meaning in the equipment as well as the signs and symbols attached to the walking ratib ritual. Symbolic meanings are the meanings contained in symbols where these symbols have been added to the elements of belief which make the sacred value of a symbol higher. The purpose of this research is to describe the process, the meaning of each symbol and the symbols that exist in the running ritual. This study used a qualitative descriptive approach using symbolic interaction theory. To obtain accurate data and informants, the data collection techniques used were observation, interviews and documentation. The results showed that each symbol in the walking ritual equipment had its own meaning which had been mutually agreed upon so that it could be understood by all of the community.
\end{abstract}

Keywords: Meaning, Symbols, Symbolic Interaction, Ritual Ratib Walking 


\section{A. Pendahuluan}

Upacara adat adalah salah satu tradisi masyarakat tradisional yang masih dianggap memiliki nilai-nilai yang masih cukup relevan bagi kebutuhan masyarakat pendukungnya. Selain sebagai usaha manusia untuk dapat berhubungan dengan arwah para leluhur, juga merupakan perwujudan kemampuan manusia untuk menyesuaikan diri secara aktif terhadap alam lingkungannya dalam arti luas.

Hubungan antara alam dan manusia adalah sebuah keharusan yang tidak dapat di tolak, karena hubungan tersebut memiliki nilai-nilai sakral yang sanggat tinggi. Hal ini diungkapkan dalam personifikasi mistik kekuatan alam, yakni kepercayaan kepada makhluk gaib, kepercayaan pada sang pencipta atau dengan mengkonseptualisasikan hubungan antara berbagai kelompok sosial sebagai hubungan antara binatang-binatang, burung-burung atau kekuatan alam (Keesing, 1992:131).

Upacara adat erat kaitannya dengan ritual-ritual keagaman atau disebut juga dengan ritus. Ritus adalah alat manusia religius untuk melakukan perubahan. Ia juga dikatakan sebagai simbolis agama, atau ritual itu merupakan "agama dan tindakan". Ritual keagaman yang dilakukan oleh masyarakat berdasarkan kepercayaan yang dianut oleh masyarakat, kepercayaan seperti inilah yang mendorong manusia untuk melakukan berbagai perbuatan atau tindakan yang bertujuan mencari hubungan dengan dunia gaib penguasa alam melalui ritualritual, baik ritual keagamaan (religious ceremonies) maupun ritual-ritual adat lainnya yang dirasakan oleh masyarakat sebagai saat-saat genting, yang biasa membawa bahaya gaib, kesengsaraan dan penyakit kepada manusia maupun tanaman (Koentjaraningrat, 1985:243-246).

Tradisi atau kebiasaan merupakan sesuatu yang dilakukan sejak lama dan menjadi bagian dari kehidupan suatu kelompok masyarakat, biasanya dalam suatu negara, kebudayaan, waktu dan agama yang sama. Hal yang paling mendasar dari tradisi adalah adanya informasi yang diteruskan dari generasi ke generasi lainnya baik secara lisan maupun tulisan. Seperti di Aceh Tamiang yaitu Desa Sungai Kuruk III yang mana masyarakatnya masih memengang teguh adat istiadat yang ada di 
desanya salah satunya adalah sebuah tradisi yang biasa dilakukan di penghujung bulan Safar, yang dilaksanakan oleh masyarakat Sungai Kuruk III dengan tujuan untuk menghindari dari kejadian buruk, sial, nasib tidak baik yang dianggap sebagai bencana. Tradisi ini ialah tradisi tolak bala dengan berbagai macam ritualritual yang dilakukan dalam tradisi tersebut. Ritual-ritual tersebut ialah ritual Ratib Duduk, Ritual Ratib Berjalan, Kenduri Kobah (kenduri di kuburan keramat), dan Kenduri Laut. Dari berbagai ritual yang ada pada tradisi tolak bala penulis ingin meneliti tentang Ritual Ratib Berjalan yang sampai saat ini masih di laksanakan dengan tujuan untuk mengusir roh-roh jahat yang mengganggu masyarakat.

Ratib Berjalan adalah sebuah ritual yang dilakukan oleh sekelompok orang dengan cara berdzikir yang dilakukan pada malam hari setelah sholat isya yang dilakukan secara bersama-sama oleh kaum lelaki sepanjang jalan desa Sungai Kuruk III dari awal masuknya desa tersebut hingga kepenghujung desa. Ratib berjalan tidaklah sama dengan ratib duduk. Ratib berjalan mempunyai tujuan untuk mengusir roh-roh yang dianggap jahat dari perbatasan desa hingga ke penghujung desa. Sedangkan ratib duduk hanya meminta permohonan dari Allah Swt untuk dijauhkan dari bala.

Dalam melakukan prosesi ritual ratib berjalan ini memiliki makna dan simbol-simbol yang tidak tereskpresikan secara langsung. Makna simbol yang tidak terekspresikan oleh kata-kata dapat diamati melalui perlengkapan ritual seperti bendera, cambuk, lampu obor, selain itu terdapat juga simbol simbol yang lainnya seperti pakaian putih yang di gunakan oleh syeh/pemimpin ratib berjalan, lampu rumah masyarakat yang harus dimatikan dan dilakukan setelah sholat isya dalam keadaan yang gelap, serta terdapat pantangan-pantangan selama ratib berjalan ini berlangsung. Lambang atau simbol adalah sesuatu yang digunakan untuk menunjukkan sesuatu lainnya, berdasarkan kesepakatan sekelompok orang. Dalam kamus Bahasa Indonesia karangan WJS Poerwadarminta disebutkan simbol atau lambang adalah semacam tanda, lukisan, perkataan, lencana dan sebagainya yang menyatakan sesuatu hal atau mengandung maksud tertentu (Sobur, 2004:156). Dalam ritual ratib berjalan ini simbol yang digunakan adalah cambuk yang terbuat dari lidi yang dililitkan dengan menerong (rumput tetemi), 
sedangkan bendera yang digunakan terbuat dari kain putih berlafadzhkan Laillahaillallah dengan menggunakan spidol yang ditulis oleh imam kampong, pakaian putih yang dikenakan oleh syeh/pemimpin ratib berjalan serta simbolsimbol lainnya yang dijadikan sebagai perlengkapan dalam melaksanakan ritual tersebut. Selain itu selama ritual ratib berjalan berlangsung semua masyarakat harus mematikan semua lampu yang ada dirumahnya sehingga semua rumah yang ada di desa tersebut akan gelap tanpa ada cahaya dan sepi, hanya ada cahaya obor yang digunakan oleh masyarakat yang melaksanakan ratib berjalan ini. Hal ini merupakan suatu peristiwa yang memiliki makna dan nilai-nilai yang harus dipahami oleh masyarakat dari generasi ke generasi. Setiap simbol yang digunakan dalam ritual ini juga memiliki makna tertentu yang sangat di percayai oleh para tetua adat dan perangkat dikampung.

Hovland mengatakan bahwa komunikasi adalah proses mengubah perilaku orang lain (communication is the process to modify the behavior of other individuals). Akan tetapi seseorang dapat mengubah sikap, pendapat atau perilaku orang lain apabila komunikasinya itu memang komunikatif seperti telah diuraikan komunikasi adalah suatu proses yang berlangsung secara terus menerus (mengalami perkembangan yang bearti) sejalan dengan tingkat perkembangan masyarakat. Proses komunikasi itu sendiri terbagi dalam dua tahap yaitu komunikasi primer dan komunikasi sekunder (Effendy, 2004:10-11).

Salah satu fungsi dari komunikasi ialah menurunkan warisan sosial dari satu generasi ke generasi berikutnya, maka dari itu hal yang paling mendasar dari sebuah adat istiadat adalah adanya informasi yang di teruskan dari satu generasi ke generasi berikutnya baik tertulis maupun lisan, karena tanpa adanya proses transformasi informasi dari generasi ke generasi berikutnya maka suatu adat atau tradisi akan punah. Proses komunikasi yang mereka lakukan ialah secara primer dimana mereka berkomunikasi dengan kelompoknya melalui simbol-simbol yang mereka gunakan pada saat melalukan ritual ini, sehingga tanpa berkomunikasi secara langsung mereka tetap bisa berkomunikasi melalui bahasa isyarat dengan menggunakan simbol-simbol tersebut.

Masyarakat Sungai Kuruk III mengganggap ritual ini sangatlah sakral sehingga proses komunikasi dalam ritual ratib berjalan telah diciptakan dan diberi 
pemaknaan terhadap simbol-simbol tertentu sehingga makna simbolik prosesi ini menjadi sangat penting dan bervariasi. Didalam simbol tersebut dimasukkanlah unsur-unsur keyakinan yang membuat semakin tingginya nilai sakralitas sebuah simbol. Namun sebagian masyarakat ada yang tidak tertarik untuk mengkaji lebih dalam tentang makna-makna simbolik dari simbol yang ada pada ritual ratib berjalan ini, mereka hanya melaksanakan ratib berjalan saja tanpa menyadari esensi dari ritual tersebut. Bahkan dari tetua atau tokoh adat tidak menyampaikan makna simbolik yang ada pada perlengkapan ritual ratib berjalan ini kepada masyarakat, sehingga berimbas negatif terhadap ritual ini yang mana hanya tetua dan tokoh adat yang memahami, sedangkan generasi muda tidak ada yang tahu makna simbolik dari ritual ratib berjalan ini.

Alasan masyarakat melakukan ritual ini hanyalah untuk mengusir roh jahat yang mengganggu keluarga mereka tanpa mereka ketahui makna dari setiap ritual yang mereka lakukan. Namun seiring dengan perkembangan zaman kearah yang modern banyak pengaruh-pengaruh luar yang masuk ke dalam kehidupan masyarakat. Banyaknya masyarakat desa Sungai Kuruk III khususnya generasi muda masih ada yang tidak mengetahui dan memahami makna dan simbol yang terkandung dalam ritual ratib berjalan tersebut. Oleh sebab itu fenomena ini penting untuk diteliti agar masyarakat memahami makna simbolik yang terkandung dalam ritual ratib berjalan karena pada setiap rangkaian dan kegiatan ritual ratib berjalan terdapat simbol-simbol dan perilaku non-verbal yang mempunyai makna tertentu dan merupakan salah satu upaya untuk melestarikan ritual tersebut agar tetap terjaga sampai kapan pun.

Berdasarkan penjelasan ini, maka penulis tertarik untuk mengetahui lebih dalam terkait dengan bagaimana prosesi ritual ratib ini berjalan serta apa makna simbol-simbol yang terdapat pada ritual ratib di Desa Sungai Kuruk III Kecamatan Seruway Kabupaten Aceh Tamiang. 


\section{B. Metode Penelitian}

Penelitian ini dilakukan di Desa Sungai Kuruk III, Kecamatan Seruway Kabupaten Aceh Tamiang. Alasan peneliti melakukan penelitian di desa sungai kuruk III yaitu karena desa tersebut masih melaksanakan adat yang turun temurun yaitu ritual ratib pada awal bulan safar, sebagai salah satu ritual yang di percayai untuk mengusir roh-roh jahat yang ada di desa tersebut. penulis menggunakan pendekatan metode penelitian berjalan yang dilakukan kualitatif bersifat deskriptif karena melalui pendekatan tersebut berdasarkan fenomenologi dapat melakukan pemecahan masalah yang diselidiki secara mendalam dengan melukiskan keadaan subjek dan objek penelitian saat sekarang berdasarkan faktafakta yang bersifat deskriptif (Sugiyono,2017:292), karena permasalahan belum jelas, holistik, kompleks, dinamis dan penuh makna sehingga tidak mungkin data pada situasi sosial tersebut dijaring menggunakan metode kuantitatif dengan instrument seperti pedoman wawancara.

Dalam penelitian ini informan penelitian yang digunakan penulis adalah teknik snowballsampling. Teknik snowballsampling adalah teknik penentuan sampel yang mula-mula jumlahnya kecil, kemudian membesar. Ibarat bola salju yang menggelinding yang lama-lama menjadi besar, dalam menentukan sampel mula-mulaa dipilih satu atau dua orang, tetapi karena dua orang belum merasa lengkap terhadap data yang diberikan, maka peneliti mencari orang lain untuk melengkapi data-data yang masih kurang (Sugiyono, 2017:219). Teknik snowball sampling ini merupakan teknik yang dilakukan berdasarkan populasi ada ciri-ciri atau sifat-sifat tertentu yang diperkirakan mempunyai sangkut paut erat dengan ciri-ciri atau sifat-sifat yang spesifik yang ada dan dilihat dari populasi dijadikan kunci untuk pengambilan sampel. Adapun informan dalam penelitian ini ialah ketua adat yang peneliti jadikan sebagai informan kunci, melalui informan kunci maka peneliti akan menelusuri informan-informan lainnya untuk mendapatkan informasi tambahan mengenai ritual ratib berjalan.

Teknik pengumpulan data merupakan langkah yang paling strategis dalam penelitian, karena tujuan utama dari penelitian adalah mendapatkan data. Adapun teknik pengumpulan data yang digunakan dalam penelitian ini dengan melakukan metode observasi partipasif Dalam penelitian ini peneliti melakukan observasi 
partisipasi pasif yaitu observasi yang dilakukan dengan cara peneliti datang ke tempat kegiatan orang yang diamati tetapi tidak ikut terlibat dalam kegiatan tersebut. Hal ini dikarena kegiatan ritual ratib berjalan dilakukan pada malam hari dan hanya dilakukan oleh kaum lelaki.Wawancara merupakan pertemuan dua orang untuk bertukar informasi dan ide melalui tanya jawab, sehingga dapat dikontruksikan makna dalam suatu topik tertentu (Sugiyono, 2017:231) . Dalam melakukan wawancara dalam penelitian ini peneliti menggunakan wawancara terstruktur.

Wawancara terstruktur adalah wawancara yang di lakukan dimana pengumpul data telah menyiapkan pertanyaan yang akan diajukan kepada informan. Dalam penelitian ini peneliti akan mewawancara informan penelitian yaitu perangkat desa serta masyarakat desa sungai kuruk III. Dokumentasi merupakan peristiwa yang sudah berlalu, dokumentasi bisa berupa bentuk tulisan, gambar, atau karya-karya monumental seseorang (Sugiyono, 2017:240). Studi dokumentasi merupakan pelengkap dari penggunaan metode observasi dan wawancara dalam penelitian kualitatif dalam mendapatkan gambaran dari sudut pandang objek yang berbeda.

Adapun teknik analisis data yang digunakan dalam penelitian ini adalah analisis kualitatif serta hasil wawancara ditampilkan untuk mendukung analisis data. Analisis data yang digunakan dalam memecahkan masalah yang timbul dari penelitian sejak awal sampai selesai pengumpulan data.

\section{Kajian Teoretis}

\section{Teori Interaksi Simbolik}

Teori Interaksi Simbolik merupakan teori yang menjelaskan tentang bagaimana cara berpikir mengenai pikiran (mind), diri dan masyarakat. Teori ini mengajarkan bahwa ketika manusia berinteraksi satu sama lainnya, mereka saling membagi makna untuk jangka waktu tertentu dan untuk tindakan tertentu. George Herbert Mead dipandang sebagai pembangun paham interaksi simbolis ini, ia mengajarkan bahwa makna muncul sebagai hasil interaksi diantara manusia baik secara verbal maupun nonverbal melalui aksi dan respons yang terjadi, kita 
memberikan makna kedalam kata-kata atau tindakan dan kita dapat memahami suatu peristiwa dengan cara-cara tertentu ( Morissan, 2013:110).

Interaksi simbolik ini lahir karena individu berinteraksi satu sama lainnya sehingga menghasilkan ide-ide dasar dalam membentuk makna yang berasal pada pikiran manusia mengenai dirinya dan hubungannya di tengah interaksi sosial, dan bertujuan untuk memediasi serta menginterpretasikan makna di tengah masyarakat, dimana individu tersebut menetap.

Pada dasarnya interaksi manusia menggunakan simbol-simbol, cara manusia menggunakan simbol mempresentasikan apa yang mereka maksudkan untuk berkomunikasi dengan sesamanya. Teori interaksi simbolik menekankan pada hubungan antara simbol dan interaksi, serta inti dari pandangan pendekatan ini adalah individu. Banyak ahli dibelakang perspektif ini mengatakan bahwa individu merupakan hal paling penting dalam konsep psikologi sosial. Mereka mengatakan bahwa individu adalah objek yang bisa secara langsung ditelaah dan dianalisis melalui interaksinya dengan individu yang lain (Soeprapto, 2007:11).

Titik tolak ukur teori interaksi simbolik berasumsi bahwa manusia membentuk makna melalui proses komunikasi. Menurut Nugroho (2015:5) Interaksi Simbolik berfokus pada pentingnya membentuk makna bagi perilaku manusia, dimana dalam teori interaksi simbolik tidak bisa dilepaskan dari proses komunikasi karena awalnya makna itu tidak ada artinya sampai akhirnya dikontruksikan secara interpretif oleh individu melalui proses interaksi, Untuk menciptakan makna yang dapat disepakati bersama.

\section{Aplikasi Teori Interaksi Simbolik dalam Masyarakat}

Teori interaksi simbolik pleh para ahli dipandang sebagai pendatang baru dalam studi ilmu komunikasi, yaitu sekitar awal abad ke-19 yang lalu. Sampaiakhirnya teori interaksi simbolik terus berkembang hingga saat ini, dimana secara tidak langsung teori ini merupakan cabang sosiologi dari perspektif interaksional, (Fisher, 2006:129). Interaksi simbolik menurut perspektif interaksional, merupakan salah satu perspektif yang ada dalam studi ilmu komunikasi yang barangkali bersifat "humanis".

Perspektif ini sangat menonjolkan keagungan dan maha karya nilai individu diatas pengaruh nilai-nilai yang ada selama ini. Perpektif ini juga menganggap 
setiap individu di dalam dirinya memiliki esensi kebudayaan, berinteraksi ditengah sosial masyarakatnya, dan menghasilkan makna "buah pikiran" yang disepakati secara kolektif. Dan pada akhirnya, dapat dikatakan bahwa setiap individu akan mempertimbangkan sisi individu tersebut, inilah salah satu ciri dari perspektif interaksional yang bealiran interaksionisme simbolik.

Semua makna budaya diciptakan dengan menggunakan simbol-simbol, kata James P. Spradley. Makna hanya dapat disimpan didalam "simbol", ujar Clifford Geertz. Semua simbol, baik kata-kata yang terucapkan, sebuah objek seperti sebuah bendera, suatu gerak tubuh seperti melambaikan tangan, sebuah tempat seperti mesjid, atau suatu peristiwa seperti perkawinan, merupakan bagian-bagian suatu sistem simbol. Simbol adalah objek atau peristiwa apapun yang menunjukkan pada sesuatu. Simbol itu meliputi apapun yang kita rasakan atau alami (Sobur, 2004:177).

\section{Pembahasan}

\section{Prosesi Ritual Ratib Berjalan Di Desa Sungai Kuruk III}

Proses merupakan langkah-langkah sistematika yang dilakukan oleh sekelompok orang untuk menghasilkan serangkaian tindakan atau perbuatan agar tersusun secara sistematis. Dalam ritual ratib berjalan ini panitia akan mempersiapkan segala keperluan sebelum melakukan ratib berjalan ini, berikut langkah-langkah yang dilakukan.

1. Musyawarah

Persiapan untuk melaksanakan ritual ratib berjalan ini dimulai dengan mengadakan musyawarah (rapat) yang dilakukan oleh kepala adat, pawang laut, imam desa serta perangkat desa Sungai Kuruk III. Dalam rapat ini mereka akan merundingkan apa-apa saja yang perlu dipersiapkan dan kapan waktu pelaksanaannya. Tujuan musyawarah ini diharapkan dapat membentuk pelaksanaan ratib berjalan agar berjalan sebagaimana mestinya serta membentuk panitia persiapan ratib berjalan. Menurut hasil wawancara dengan kepala adat desa sungai kuruk III menyatakan:

"Ritual ratib berjalan ini dilakukan setiap tahunnya sehingga perlu persiapan yang matang karena melibatkan sekelompok orang dan bukan 
untuk kepenting pribadi saja, dan musyawarah ini dilakukan bersama kepala adat, pawang laut serta perangkan desa lainnya (wawancara, 25 Januari 2020)".

Berdasarkan wawancara di atas, dapat disimpulkan bahwa masyarakat desa Sungai Kuruk III sebelum melakukan ritual ratib berjalan ini mereka akan mempersiapkan segala keperluan atau peralatan untuk melaksanakan ritual ini, hal ini dikarenakan ritual ini tidak hanya melibatkan satu orang saja melainkan banyak orang.

\section{Waktu Dan Tempat}

Setelah mengadakan musyawarah maka kepala adat, pawang laut, serta panitia dan perangkat desa menyepakati dan menetapkan kapan acara tersebut dilakukan dan dimana tempat pelaksanaan kenduri tersebut. Waktu untuk melaksanakan ritual ratib berjalan ini dilakukan pada bulan safar atau penghabisan rabu, dilakukan pada malam hari selama 3 malam berturut-turut serta tempat pelaksanaan tersebut dilakukan di perbatasan desa sampai ke penghujung desa. Berikut hasil wawancara dari kepala adat desa Sungai Kuruk III menyatakan bahwa:

"waktu pelaksanaan ini dilakukan pada bulan safar atau penghabisan rabu, yang dilaksanakan oleh kaum lelaki pada malam hari secara bersama-sama dan tempat permualaan dilaksanakan ratib berjalan ini di awal masuknya desa sampai ke penghujung desa dengan membacakan kalimat Lailahailallah. (wawancara, 25 Januari 2020)"

Berdasarkan hasil wawancara dengan kepala adat desa sungai Kuruk III disimpulkan bahwa mereka melaksanakan ratib berjalan ini pada bulan safar dan dilakukan pada malam hari bertempat di awal masuknya desa sampai ke penghung desa.

\section{Mempersiapkan Peralatan}

Sebelum memulai acara ratib berjalan panitia akan mempersiapkan peralatan seperti cambuk, bendera, obor yang akan dipersiapkan oleh panitia yang akan dibawa pada saat pelaksanaan ratib berjalan dilakukan. Peralatan ini akan digunakan dalam proses ritual ratib berjalan nantinya mereka juga akan mengabarkan kepada masyarakat untuk mematikan lampu dan tidak pulang melaut pada saat pelaksanaan ratib berjalan berlangsung. 


\section{Pelaksanaan Ritual Ratib Berjalan}

Ritual ratib berjalan dimulai setelah sholat isya, mereka akan berkumpul di satu titik yaitu di awal masuknya desa, panitia akan mengabarkan kepada semua warga khususnya lelaki untuk berkumpul di awal desa. Selain itu panita juga akan memastikan disetiap rumah bahwa telah mematikan lampu agar saat pelaksanaan ratib berjalan ini berlangsung dengan khusyuk tanpa adanya gangguan. Setelah semua berkumpul maka mereka akan memulai dengan pemimpin yang akan membacakan doa khusus didalam hatinya kemudian dilanjutkan dengan mengumandangkan kalimat Lailahailallallah yang akan diikuti oleh pengikut ratib berjalan dari mulai awal masuknya desa sampai ke penghujung desa.

Selama ratib berjalan ini berlangsung mereka mengumandangkan syair Lailahailallah disepanjang jalan dengan membawa cambuk dan bendera serta obor yang digunakan sebagai penerang jalan karena saat pelaksanaan ini semua lampu rumah warga harus dimatikan agar ratib ini berjalan dengan khusyuk.

\section{Makna Simbol pada Peralatan Yang Digunakan Pada Ritual Ratib Berjalan}

Dalam suatu ritual atau pun tradisi memiliki media atau peralatan yang digunakan untuk melaksanakan prosesi ritual tersebut. Media atau peralatan merupakan sesuatu yang paling penting dalam sebuah acara, media merupakan simbol yang memiliki makna tertentu sehingga media tersebut dijadikan sebagai salah satu pelengkap untuk prosesi ritual, dengan menggunakan media tertentu suatu ritual bisa mencapai tujuan yang diinginan. Tanpa media tersebut, suatu ritual tidak mungkin dapat dilaksanakan. Adapun media atau simbol yang digunakan pada ritual ratib berjalan di desa Sungai Kuruk III yaitu cambuk, bendera, obor, pakaian putih dan lain sebagainya.

Setiap simbol tersebut memiliki makna-makna tersendiri yang telah disepakati oleh sekumpulan masyarakat. Berikut ini hasil wawancara dengan kelima informan mengenai makna dari setiap simbol yang digunakan dalam pelaksanaan ritual ratib berjalan ini. Dalam ritual ratib berjalan cambuk menjadi salah satu simbol yang digunakan untuk mengusir roh-roh jahat yang mengganggu masyarakat Sungai Kuruk III, didalam cambuk yang digunakan tersebut memiliki 
makna tersendiri sehingga dijadikan sebagai peralatan untuk melaksanakan kegiatan ini.

\section{Cambuk}

\section{Gambar 1. Cambuk}

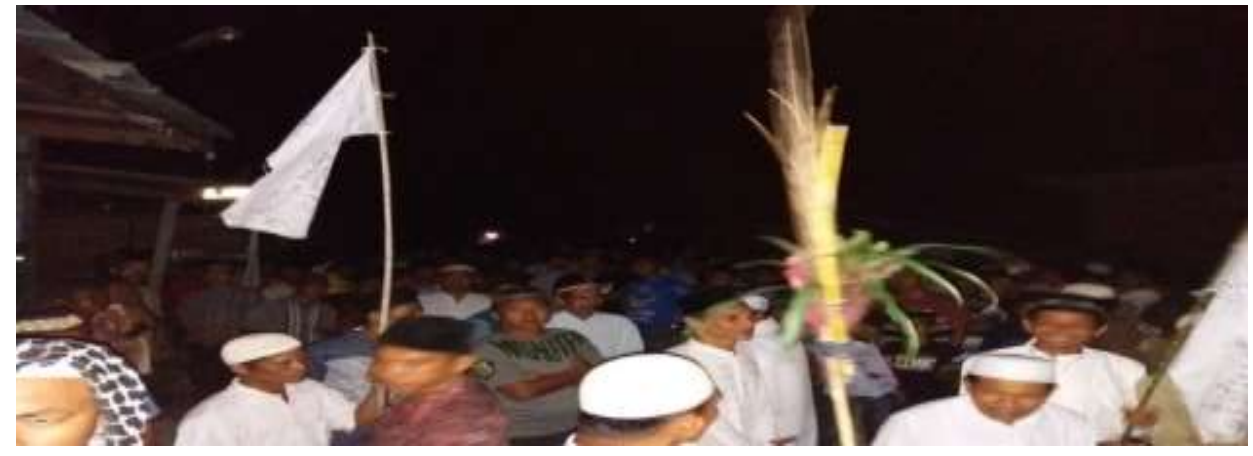

Sumber: Dok.Peneliti 2020

Cambuk atau cemeti merupakan peralatan yang digunakan dalam melakukan ritual ratib berjalan. Cambuk ini terbuat dari lidi aren dan bambu kuning yang diikat menjadi satu, dahulu masyarakat membuat cambuk menggunakan tali menerong (rumput tetemi). Namun karena sulitnya mencari rumput tetemi maka mereka menggatinya dengan menggunakan lidi dan bambu kuning, hal ini bermakna bahwa lidi dan bambu dapat mengusir roh-roh jahat yang mengganggu masyarakat tersebut. Sebenarnya tidak ada maksud untuk mempercayai benda tersebut tetapi karena sudah menjadi tradisi dan adat istiadat maka dipakailah lidi dan bambu kuning sebagai salah satu peralatan dalam ritual ratib berjalan ini. Berikut ini hasil wawancara dari kelima informan. Menurut bapak Rahimuddin sebagai ketua adat didesa Sungai Kuruk III menyatakan:

"cambuk yang kita gunakan disini terbuat dari lidi aren dan bambu kuning dimana lidi diikat di bambu kuning, masyarakat menggunakan lidi dan bambu karena sudah menjadi adat istiadat dari nenek moyang dahulu menggunakan lidi dan bambu untuk mengusir roh-roh jahat yang mengganggu desa ini, pernah juga dibuat menggunakan tali menerong (rumput tetemi) namun dikarenakan sulit untuk mencari bahan tersebut maka dipakailah lidi dan bambu"._Rahimuddin (wawancara 25 Januari 2020)

Selanjutnya bapak Abdul Saman yang di jadikan sebagai panglima laut didesa Sungai Kuruk III mengatakan bahwa: 
"saya sebagai panglima laut disini bertugas sebagai pemimpin dalam melakukan ratib berjalan ini peralatan yang saya bawa yang paling utama yaitu cambuk, karena dengan cambuk inilah saya mengusir setan-setan yang mengganggu desa ini. Cambuk ini dibuat menggunakan lidi dan bambu yang mempunyai makna bahwa lidi dan bambu ini kedua benda yang ditakutkan setan dan dibuat dari kedua benda ini karena dari zaman nenek moyang dahulu mereka membuat cambuk menggunakan kedua benda ini sampailah saat ini cambuk masih terbuat dari kedua benda ini"._Abdul Saman (wawancara, 30 Januari 2020).

Berdasarkan hasil wawancara yang penulis pilih untuk mendapatkan informasi mengenai makna dari simbol cambuk yang digunakan pemimpin ratib berjalan saat melakukan ratib berjalan ini. Penulis simpulakan bahwa cambuk ini terbuat dari lidi dan bambu yang mempunyai makna bahwa lidi dan bambu ini ditakuti oleh syetan dan roh-roh yang mengganggu masyarakat Sungai Kuruk III, hal ini juga dikarenakan cambuk yang terbuat dari lidi dan bambu ini telah digunakan dari nenek moyang dahulu sehingga menjadi kebiasaan masyarakat membuat cambuk menggunkan kedua benda ini.

2. Bendera yang bertuliskan kalimat Lailahaillallah

\section{Gambar 2. Bendera}

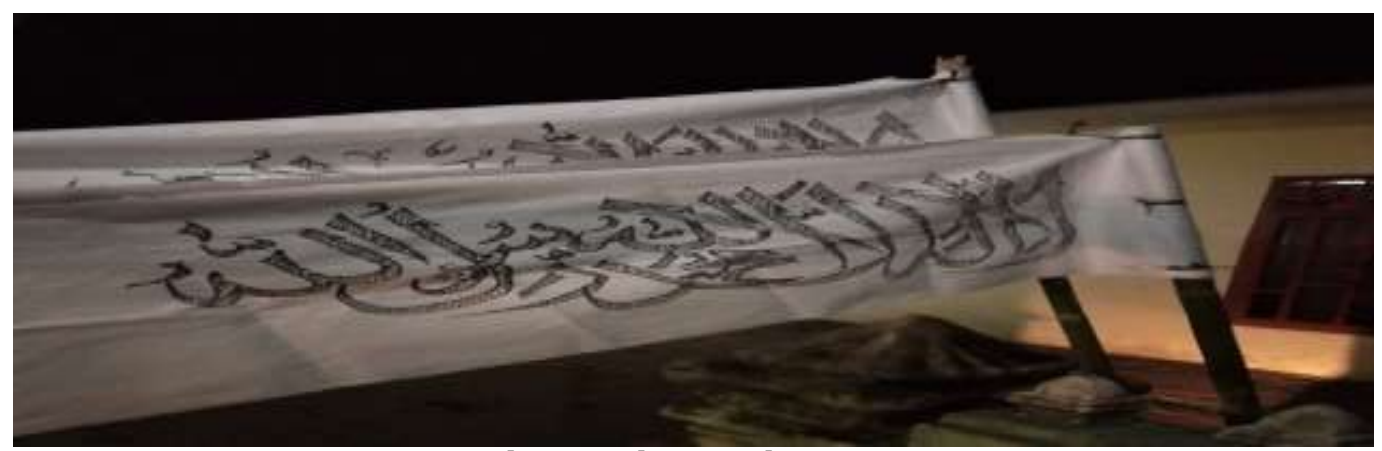

Sumber: Dok. Peneliti 2020

Selain cambuk ada juga beberapa simbol lainnya yaitu bendera yang terbuat dari kain putih yang bertuliskan kalimat Lailahaillallah yang dibuat oleh masyarakat Sungai Kuruk III untuk dibawa pada saat melakukan ratib berjalan. Bendera putih bertuliskan kalimat Lailahaillallah mempunyai makna bahwa kain putih tersebut melambangkan kesucian atau bersih dan bendera Rasulullah juga berwarna putih oleh sebab itu masyarakat membuat bendera tersebut dengan menggunakan kain warna putih sehingga dijadikan sebagai simbol dalam prosesi 
ritual ratib berjalan ini. Bendera ini juga dimaknai sebagai tanda untuk berperang melawan syetan atau roh-roh jahat yang mengganggu masyarakat. Berikut ini hasil wawancara dengan kepala adat desa Sungai Kuruk III mengenai bendera putih mengatakan bahwa:

"Bendera yang digunakan disini adalah bendera yang berwarna putih yang bertuliskan kalimat Lailahaillallah, bermakna bahwa kain yang berwarna putih itu merupakan warna suci dan bersih, bendera yang di bawa sebagai tanda untuk berperang melawan syetan atau roh-roh yang mengganggu masyarakat Sungai Kuruk III”._Rahimuddin (wawancara, 25 januari 2020)

Dari kajian lapangan dapat disimpulkan bahwa bendera ini terbuat dari kain yang berwarna putih yang bertuliskan kalimat Lailahailallah dimana bermakna bahwa kain putih tersebut melambambangkan kesucian atau bersih oleh dan juga bendera Rasulullah juga berwarna putih oleh sebab itu masyarakat membuat bendera tersebut dengan menggunakan kain warna putih.

\section{Jubah atau Pakaian Putih}

\section{Gambar. 3. Jubah atau Pakaian Putih}

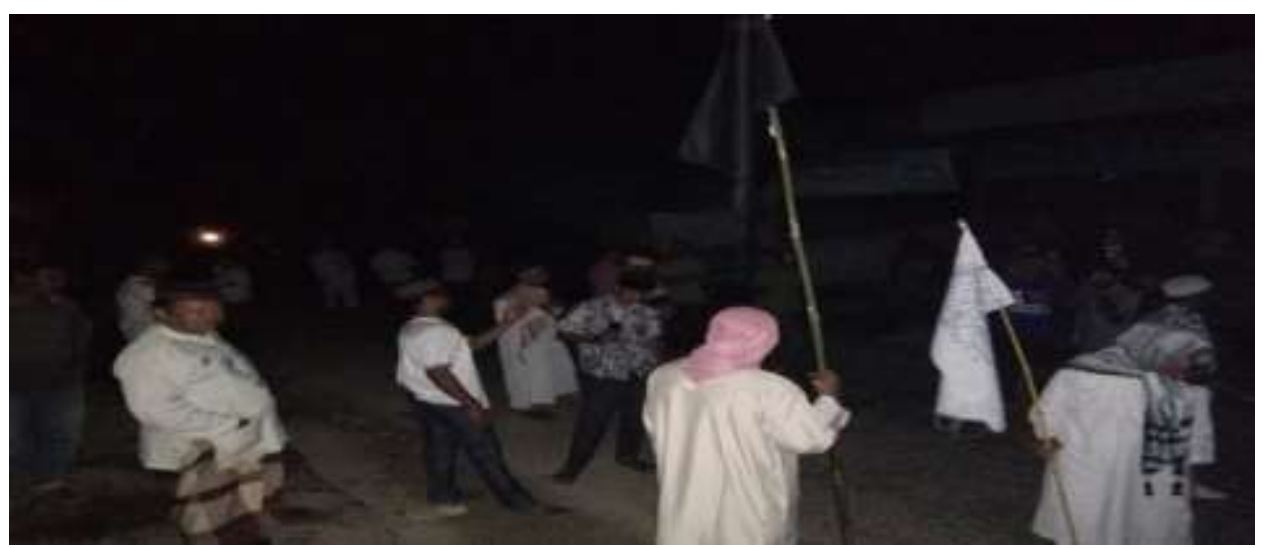

Sumber: Dok. Peneliti 2020

Selain bendera juga ada simbol lain yaitu pakaian putih atau jubah yang dikenakan oleh pemimpin ratib berjalan. Pakaian putih ini dimaknai bahwasan nya pakaian yang berwarna putih berarti bersih dan suci sehingga cocok digunakan untuk ritual ratib berjalan ini yang dikenakan oleh pemimpin dan boleh juga dikenakan oleh pengikut ratib berjalan. Berikut hasil wawancara dari kelima 
informan mengenai jubah atau pakaian putih yang ada dalam prosesi ritual ratib berjalan.

Pemakaian baju jubah putih ini oleh syekh atau pemimpin itu bermakna suci dan bersih, karena warna putih itu melambangkan suci sehingga dipilihlah warna putih sebagai pakaian yang dikenakan saat pelaksanaan ratib berjalan ini.

4. Lampu Obor

Selanjutnya simbol yang dibawa saat melakukan ratib berjalan ini yaitu lampu obor yang dibuat dengan bambu yang mereka gunakan sebagai lampu untuk menerangi jalan saat pelaksanaan ratib berjalan ini. Tidak ada makna khusus hanya sebagai penerang jalan karena pada zaman dahulu belum adanya aliran listrik seperti sekarang ini, sehingga mereka menggunakan lampu obor sebagai penerang jalan mereka. Sekarang obor tetap digunakan karena sudah menjadi simbol peralatan yang harus dibawa saat melakukan ritual ratib berjalan ini.

Penggunaan lampu obor saat pelaksanaan ratib berjalan ini dijadikan sebagai penerang jalan untuk mempermudah mereka dalam melakukan ritual ratib berjalan. Pada saat mereka melaksanakan prosesi ritual ratib berjalan ini semua warga harus mematikan lampu oleh sebab itulah peratib menggunakan obor sebagai penerang jalan saat mereka melakukan prosesi ini.

\section{Hanya dilakukan oleh Kaum Lelaki}

Dalam ritual ratib berjalan ini hanya boleh dilakukan oleh kaum adam atau lelaki karena dipercayai kaum lelaki lebih kuat daripada perempuan, ritual ini juga dilakukan pada malam hari sehingga perempuan dilarang untuk keluar rumah selama ratib berjalan ini berlangsung dan dilakukan oleh kaum lelaki saja yang mana perempuan sangat lemah dan ditakutkan terjadi hal-hal yang tidak diinginkan sehingga tidak diperbolehkan mengikuti ratib berjalan ini.

6. Pantangan Menghidupkan Lampu Dan Pulang Melaut Saat Pelaksanaan Ritual Ratib Berjalan

Berikut ini beberapa pantangan yang harus dipatuhi oleh masyarakat Sungai Kuruk III saat pelaksanaan prosesi ritual ratib berjalan ini. Pantangan ini 
dibuat agar masyarakat mematuhi dan tidak melanggar setiap pantangan yang telah disepakati bersama. Beberapa pantangan tersebut adalah larangan untuk menghidupkan lampu saat ritual itu dilakukan serta larangan untuk tidak pulang melaut saat pelaksanaan ratib berjalan ini. Pantangan ini juga dimaknai agar para peratib lebih khusyuk dalam melakukan ritual tanpa adanya gangguan dari masyarakat.

\section{Syair/Kalimat (Laillahaillallah)}

Selain simbol nonverbal ada juga simbol verbal yang dibacakan oleh para peratib saat melaksanakan ratib berjalan. Syair/kalimat Laillahaillallah merupakan syair yang dilantunkan disepanjang jalan oleh para peratib yang dimaknai bahwa kalimat Laillahaillallah bermakna tidak ada tuhan yang berhak disembah selain Allah. Mereka percaya bahwa Allah itu Esa . Oleh sebab itu setiap yang mengikuti ratib berjalan ini haruslah mereka yang beragama Islam serta dalam keadaan bersih, karena ritual ini merupakan ritual yang sakral yang telah dilakukan dari zaman dahulu.

Syair ini dibacakan disepanjang jalan desa Sungai Kuruk III mereka bertasbih dengan tujuan untuk mengusir segala penyakit atau gangguan roh-roh jahat yang mengganggu desa Sungai Kuruk III di mulai dari awal masuknya desa sampai ke penghujung desa. Pemimpin akan memimpin pengikut ratib dan pemimpin membawa cambuk yang telah di buat sebelum ratib ini berlangsung.

\section{Tanda-Tanda Atau Simbol-Simbol Yang Melekat Pada Ritual Ratib Berjalan}

Tanda atau simbol pada suatu prosesi dijadikan sebagai lambang sebagai cara untuk berkomunikasi dengan orang sekitar melalui simbol. Sebuah simbol atau kumpulan simbol-simbol bekerja dengan menghubungkan sebuah konsep, ide umum, pola atau bentuk. Suatu tanda atau simbol merupakan suatu stimulus yang menandai kehadiran sesuatu yang lain dimana suatu tanda tersebut mempunyai hubungan erat dengan tindakan atau maksud yang sebenarnya. Makna yang kita berikan pada sebuah simbol merupakan hasil interaksi sosial yang 
menggambarkan kesepakatan untuk menerapkan makna ynag terdapat pada simbol tersebut (Abdurrohman, 2015:29-30).

Dalam pelaksanaan ritual ratib berjalan ini mempunyai simbol-simbol yang dijadikan sebagai bentuk komunikasi untuk berinteraksi. Simbol-simbol yang berupa benda mereka gunakan sebagai pelengkap dalam melaksanakan ratib berjalan ini.

\section{Proses Ritual Ratib Berjalan Pada Tradisi Tolak Bala}

Proses merupakan langkah-langkah sistematika yang dilakukan oleh seseorang atau sekelompok orang untuk menghasilkan serangkaian tindakan atau perbuatan. Dalam tradisi tolak bala ada salah satu ritual yang biasa dilakukan oleh masyarakat desa Sungai Kuruk III yaitu Ritual Ratib Berjalan. Ratib yaitu susunan atau suatu rangkaian dzikir, sedangkan berjalan yaitu berjalan, jadi Ratib berjalan adalah suatu rangkaian kegiatan dzikir yang dilakukan dengan cara berjalan berkeliling desa dengan mengucapkan kalimat tasbih yang di lakukan sepanjang desa sungai kuruk III. Dimulai dari malam hari setelah sholat isya dengan berjalan berkeliling kampung diikuti semua lapisan masyarakat membawa obor sebagai penerangan. Untuk mengusir bala keluar menuju kearah laut, sehingga terusirlah semua wabah bencana dari kampung itu. Dalam ritual ini terdapat langkahlangkah yang dilakukan dari sebelum dimulainya ritual sampai akhir ritual.

Sebelum memulai sebuah acara terdapat serangkaian langkah-langkah yang dilakukan agar acara tersebut tersusun secara sistematis dan dapat berjalan dengan lancar. Berikut ini langkah-langkah yang dilakukan sebelum memulai acara ritual ratib berjalan:

1) Musyawarah

2) Waktu dan Tempat

3) Mempersiapkan Peralatan

4) Pelaksanaan Ritual Ratib Berjalan

Langkah-langkah tersebut mereka lakukan mulai dari bermusyawarah sampai ke pelaksanaannya agar acara ratib berjalan bisa berlangsung dengan khusyuk dan sesuai dengan yang telah ditentukan. Ratib berjalan ini hanya dilakukan oleh kaum lelaki sehingga untuk observasi langsung penulis tidak bisa 
turun langsung ke lokasi penulis hanya bisa mengambil gambar sebelum acara berlangsung, pada saat ratib berjalan berlangsung penulis melihat dari dalam rumah dimana mereka secara serentak membacakan kalimat tasbih Laillahaillallah sepanjang jalan dengan pemimpin yang membawa cambuk dengan tujuan untuk mengusir roh-roh jahat yang mengganggu desa. Penulis tidak bisa mengikuti ratib berjalan ini karena tidak diwajibkan untuk perempuan mengikutinya karena perempuan dianggap lemah sehingga takut terjadi hal yang tidak diinginkan.

Berdasarkan teori yang terdapat dalam penelitian ini yaitu teori interaksi simbolik, dimana didalam teori ini mengajarkan bahwa ketika manusia berinteraksi satu sama lainnya mereka saling membagi makna untuk jangka waktu tertentu dan untuk tindakan tertentu. Melalui simbol-simbol yang digunakan mereka dapat berkomunikasi dengan sesama nya baik secara verbal maupun nonverbal melalui aksi dan respons yang terjadi.

\section{Makna Simbolik Ritual Ratib Berjalan Pada Tradisi Tolak Bala}

Semua makna budaya diciptakan dengan menggunakan simbol-simbol, kata James P. Spradley. Makna hanya disimpan didalam "simbol", ujar Clifford Geertz. Semua simbol baik kata-kata yang terucapkan, sebuah objek seperti sebuah bendera, suatu gerak tubuh, seperti melambaikan tangan, sebuah temapt seperti mesjid, atau suatu peristiwa seperti perkawinan, merupakan bagian-bagian suatu sistem simbo. Simbol adalah objek atau peristiwa apapun yang menunjukkan pada sesuatu. Simbol itu meliputi apapun yang kita rasakan atau alami (Sobur,2004:177).

Makna adalah hasil komunikasi yang penting, makna yang kita miliki adalah hasil interaksi kita dengan orang lain. Kita menggunakan makna untuk menginterpretasikan peristiwa di sekitar kita. Interpretasi merupakan proses internal didalam diri kita. Kita harus memilih, memeriksa, menyimpan, mengelompokkan dan mengirim makna sesuai dengan situasi dimana kita berada dan arah tindakan kita. Dengan demikian, jelas bahwa kita tidak dapat berkomunikasi dengan orang lain tanpa memiliki makna yang sama terhadap simbol yang kita gunakan. 
Berikut masing-masing makna simbolik dari perlengkapan yang digunakan pada saat pelaksanaan ritual ratib berjalan:

a. Cambuk yang terbuat dari lidi dan bambu yang bermakna bahwa lidi dan bambu dapat mengusir roh-roh jahat yang mengganggu masyarakat. Berdasarkan makna tersebut penulis menganalisis bahwa masyarakat mempercayai bahwa lidi tersebut merupakan benda yang ditakuti oleh syetan sedangkan bambu juga hal yang ditakuti oleh syetan maka kedua benda ini dijadikan satu sebagai perlengkapan dalam melakukan ratib berjalan. Benda ini merupakan simbol nonverbal karena berupa benda yang memiliki makna yang telah disepakati bersama.Pemimpin akan mencambuk setiap tempat-tempat yang dianggap tidak baik dengan cambuk yang dibawa pada saat ratib berjalan dilakukan dengan mengucapkan kalimat Laillahaillallah.

b. Bendera putih bertuliskan kalimat Lailahaillallah mempunyai makna bahwa kain putih tersebut melambangkan kesucian atau bersih.Berdasarkan makna tersebut penulis menganalisis bahwa mereka percaya bahwa kain putih yang mereka gunakan ini merupakan kain yang suci, mereka juga mengikuti bendera Rasulullah saat berperang yang juga berwarna putih. Oleh sebab itu mereka menggunakan bendera yang bertuliskan kalimat tasbih yang ditulis menggunakan spidol berwarna hitam untuk dibawa pada saat ritual ini dilakukan. Simbol ini merupakan simbol nonverbal karena berbentuk benda.

c. Jubah atau Pakaian putih ini dimaknai bahwasannya pakaian yang berwarna putih berarti bersih dan suci sehingga cocok digunakan untuk ritual ratib berjalan ini yang dikenakan oleh pemimpin dan boleh juga dikenakan oleh pengikut ratib berjalan.Hal ini dikarenakan warna putih merupakan warna suci yang cocok untuk digunakan dalam suatu acara yang sakral atau suci, selain warna putih mereka juga diperbolehkan menggunakan warna lain akan 
tetapi jika mereka menggunakan pakaian putih maka suatu ritual tersebut akan tersa lebih sakral.

d. Lampu obor yang dibuat dengan bambu yang mereka gunakan sebagai lampu untuk menerangi jalan saat pelaksanaan ratib berjalan ini. Tidak ada makna khusus hanya sebagai penerang jalan karena pada zaman dahulu belum adanya aliran listrik seperti sekarang ini. Obor yang digunakan peratib ini dijadikan sebagai simbol nonverbal yang mereka bawa saat pelaksanaan ratib berjalan sebagai alat untuk menerangi jalan mereka, dikarenakan semua rumah warga harus mematikan lampu agar peratib dapat fokus ketujuan utama mereka tanpa adanya gangguan dari suara-suara lainnya.

e. Hanya boleh dilakukan oleh kaum adam atau lelaki karena dipercayai kaum lelaki lebih kuat daripada perempuan, ritual ini juga dilakukan pada malam hari sehingga perempuan dilarang untuk keluar rumah selama ratib berjalan ini berlangsung. Perempuan sangatlah lemah lembut sehingga dalam hal yang berkaitan dengan ghaib mereka tidak diwajibkan untuk ikut serta karena perempuan mudah diikuti oleh hal-hal yang tidak baik, oleh sebab itu hanya lelaki yang diperbolehkan untuk mengikutinya.

f. Pantangan menghidupkan lampu dan larangan pulang melaut saat ratib berjalan, Pantangan ini juga dimaknai agar para peratib lebih khusyuk dalam melakukan ritual tanpa adanya gangguan dari masyarakat. Pantangan ini dibuat agar masyarakat lebih tertib dan mengikuti peraturan yang telah dibuat bersama, jika tidak dibuat larangan ini mereka akan sembarangan keluar dan pergi melaut tanpa mengetahui adanya pelaksaanaan ratib berjalan ini.

g. Selain simbol nonverbal ada juga simbol verbal yang dibacakan oleh para peratib saat melaksanakan ratib berjalan. Syair/kalimat Laillahaillallah merupakan syair yang dilantunkan disepanjang jalan oleh para peratib yang dimaknai bahwa kalimat Laillahaillallah bermakna tidak ada tuhan yang berhak disembah selain Allah. 
Mereka percaya bahwa Allah itu Esa. Syair ini dibacakan sepanjang jalan dengan tujuan mengusir roh-roh jahat yang menganggu desa dengan membawa cambuk yang dibawakan oleh pemimpin ratib berjalan disepanjang jalan.

Makna simbolik pada peralatan ini berkaitan dengan teori yang peneliti gunakan yaitu teori interaksi simbolik dimana Herbert Blumer mengatakan bahwa interaksi simbolik adalah interaksi yang memunculkan makna khusus dan menimbulkan interpretasi atau penafsiran. Simbolik berasal dari kata simbol yakni tanda yang muncul dari hasil kesepakatan bersama bagaimana suatu hal menjadi perspektif bersama, bagaimana suatu tindakan memberikan makna-makna khusus yang hanya dipahami oleh orang-orang yang melakukannya.

Dalam teori ini masyarakat selalu berupaya untuk menginterpretasikan setiap simbol yang digunakan oleh komunikator, dalam penelitian ini yang menjadi komunikator adalah orang yang melakukan kegiatan ratib berjalan ini yaitu tertua, tokoh masyarakat sebagai komunikan dengan menggunakan simbol, dan masyarakat yang akan memaknai simbol-simbol tersebut.

\section{E. Kesimpulan}

Berdasarkan penelitian lapangan terkait dengan ritual rateb berjalan ini, maka dapat diambil kesimpulan sebagai berikut:

Pertama, Ritual Ratib Berjalan adalah salah satu ritual yang dilakukan pada bulan safar yang merupakan bagian dari tradisi tolak bala yang ada di desa Sungai Kuruk III yang masih dilakukan sampai saat ini. Ritual Ratib Berjalan adalah dzikir yang dilakukan pada malam hari selesai sholat isya yang dilakukan oleh kaum lelaki sepanjang jalan dimulai dari awal masuknya desa sampai ke penghujung desa. Mereka akan memulai dzikir tersebut dari awal masuknya desa sungai kuruk III, dengan mengucapkan Lailahaillallah di sepanjang jalan dengan membawa bendera, cambuk dan lampu obor sebagai penerang jalan, dikarenakan semua rumah masyarakat harus mematikan lampu pada saat ritual ini dilakukan.

Kedua, Dalam melakukan ritual ini mereka menggunakan simbolsimbol/perlengkapan seperti cambuk, bendera, lampu obor, memakai baju putih, dilakukan oleh kaum lelaki serta pantangan untuk tidak menghidupkan lampu saat 
ritual ini dilakukan, semua perlengkapan tersebut memiliki makna tersendiri yang telah ada sejak zaman nenek moyang dulu dan harus tetap dilaksanakan sampai saat ini.Masyarakat Sungai Kuruk III masih melakukan ritual ini dizaman modern sebagai bentuk pewarisan budaya, adat istiadat dan tradisi yang telah turun temurun.

Ketiga, ritual ratib berjalan ini juga mengandung nilai-nilai yaitu adanya nilai religius, silahturahmi, semangat, cinta damai, tolong menolong, saling berbagi (sedekah), peduli lingkungan, kebersamaan dan nilai tanggung jawab. Nilai-nilai tersebut dapat kita dapatkan dalam budaya ratib berjalan. Jadi setelah dianalisis dari kegiatan ratib berjalan secara keseluruhan baik dari segi persiapan sampai dengan pelaksanaan ratib berjalan itu mengandung nilai-nilai kehidupan yang sangat berharga bagi masyarakat Sungai Kuruk III. Pada dasarnya secara tidak langsung ratib berjalan ini mengajarkan kita untuk terus bersyukur, terus berusaha dan berdoa kepada Allah SWT agar di jauhkan dari bahaya dan bencana. Sebab hanya kepada Allah lah kita meminta pertolongan dan perlindungan bukan kepada siapa-siapa.Semuanya kita pasrahkan kepada Allah SWT, kita hanya bisa berusaha, hasilnya yang Maha Kuasalah yang menentukan. Dengan adanya kegiatan ratib berjalan ini kepada generasi muda mampu untuk menghidupkan budaya yang sudah hampir hilang dimakan zaman 


\section{Daftar Pustaka}

Abdurrohman, Muhammad. 2015. Memahami Makna-Makna Simbolik pada Upacara Adat Sedekah Laut di Desa Tanjungan Kecamatan Kragan Kabupaten Rembang. The Messengger Volume VII, No. 1. Alumni Ilmu Komunikasi FTIK USM.

Effendy, Onong Uchjana. 2004. Ilmu Komunikasi Teori Dan Praktek. Bandung: Remaja Rosdakarya

Fisher, B. Aubrey. 2006. Teori-Teori Komunikasi. (Penyunting: Jalaluddin Rakhmat), Bandung: Remaja Rosdakarya.

https://www.academia.edu/15462995/Pengertian_Adat_Istiadat_Lengkap_Besert a_Ulasan_Dan_Definisi_Menurut_Para_Ahli. Diakses pada tgl 24 Desember 2019

Koentjaranigrat. 1985. Javanese Culture. Singapore: Oxford University Press.onlinen

RPJM (Rancangan Pembangunan Jangka Menengah) Kampong Sungai Kuruk III 2013-2018.

Manafe, Yermia Djefri. 2011. Komunikasi Ritual pada Budaya Bertani Atoni Pah Meto di Timor-Nusa Tenggara Timur. Jurnal Komunikasi, Volume 1, No. 3. Universitas Cendana Kupang, dan Kandidat Doktor Ilmu Komunikasi Universitas Padjajaran Bandung.

Morissan. 2013. Teori Komunikasi Individu Hingga Massa. Jakarta:Kencana Prenada Media Group.

Nugroho, Oki Cahyo. 2015. Interaksi Simbolik Dalam Komunikasi Budaya (Studi Analisis Faislitas Publik Di Kabupaten Ponorogo). Jurnal Aristo, Volume 3, No. 1. FISIP Universitas Muhammadiyah Ponorogo.

Sobur, Alex. 2004. Semiotika Komunikasi. Bandung: PT Remaja Rosdakarya.

Soeprapto, R. 2007. Interaksionisme Simbolik: Perspektif Sosiologi Modern. Malang:Avenroes Press.

Sugiyono. 2017. Metode penelitian Kuantitatif, Kualitatif dan R\&D. Bandung: Alfabeta. 